\title{
33. MORPHOLOGY AND AFFINITY OF THE PLANKTONIC FORAMINIFER CASSIGERINELLOITA AMEKIENSIS STOLK AND RECLASSIFICATION OF CASSIGERINELLOITA STOLK
}

\author{
Qianyu $\mathrm{Li}^{2}$ and Sally S. Radford ${ }^{2}$
}

\begin{abstract}
Cassigerinelloita amekiensis Stolk occurs abundantly in lower middle Eocene samples from the Southern Kerguelen Plateau, drilled during Ocean Drilling Program Leg 120 (Hole 749B). It showed little morphological change during its rather short evolutionary history. Because of its microperforate, pustulate wall and a triserial, pseudoplanispiral coiling mode, $C$. amekiensis appears to be related closely to co-occurring Guembelitria triseriata (Terquem). These affinities indicate that the taxa are phylogenetically related and should be classified together in the family Guembelitriidae. The potential paleoceanographic importance of these forms is also discussed.
\end{abstract}

\section{INTRODUCTION}

Stolk (1965) recorded the tiny planktonic foraminifer Cassigerinelloita amekiensis from the uppermost lower Eocene to middle Eocene of Nigeria. He believed that this new genus and species were closely related to Cassigerinella spp. Pokorny, because these genera were similar in coiling pattern and chamber arrangement. Cassigerinelloita amekiensis, however, differs from all known species of Cassigerinella in lacking the typical biserial coiling plan and the true umbilicus and in bearing supplementary sutural apertures in the adult stage. Its short range made it a good zonal marker for the ?uppermost lower Eocene to lower middle Eocene of Nigeria.

Despite its importance in biostratigraphy and its ease of identification, as reported in the original description, C. amekiensis has never been recorded outside the Niger Delta, and the original description has remained the only source for subsequent attempts for its classification. Loeblich and Tappan (1988), for example, placed this genus in the family Catapsydracidae on the basis of the original descriptions and illustrations, whereas Blow (1979) suggested that it represented "an abortive variant of a ?Globigerinita sp."

During our study of planktonic foraminifers from Hole 749B (Southern Kerguelen Plateau, Ocean Drilling Program Leg 120), we found a considerable number of specimens ascribable to $C$. amekiensis. The results from detailed observations are presented in this report.

\section{MATERIAL AND METHODS}

Site 749 is located on the western Banzare Bank of the Southern Kerguelen Plateau, at $58^{\circ} 43.03^{\prime} \mathrm{S}, 76^{\circ} 24.45^{\prime} \mathrm{E}$; Hole 749B was penetrated to $123.8 \mathrm{~m}$ below seafloor (mbsf). Thirtynine samples spanning Core 120-749B-1H through - $13 \mathrm{X}(119.8$ m) were collected as part of a study of Tertiary planktonic foraminifers (see $\mathrm{Li}$ et al., this volume).

Samples were washed through a $63-\mu \mathrm{m}$ sieve and dried; the residues were then examined. Planktonic foraminifers were picked and counted under an optical binocular microscope.

\footnotetext{
${ }^{1}$ Wise, S. W., Jr., Schlich, R., et al., 1992. Proc. ODP, Sci. Results, 120: College Station, TX (Ocean Drilling Program).

2 Department of Geology, Imperial College, Prince Consort Road, London SW7 2BP, United Kingdom.
}

Detailed observations and measurements were performed by means of a Hitachi-2500 scanning electron microscope (SEM) on selected specimens, some of which were dissected to observe the morphology of their earlier stages.

Almost all 39 samples yielded beautifully preserved planktonic foraminifers of the middle Eocene to upper Oligocene, characterized by Globigerina and Tenuitella in Cores 120$749 \mathrm{~B}-1 \mathrm{H}$ through $-2 \mathrm{H}$, and by Acarinina and Subbotina in Cores $120-749 \mathrm{~B}-3 \mathrm{H}$ through $-13 \mathrm{X}$ (no recovery in Cores 120-749B-8X and -14X). Cassigerinelloita amekiensis occurs in the lowermost 4 samples from Cores 120-749B-11X through $-13 \mathrm{X}$, an interval referable to the A. bullbrooki Zone in the lower middle Eocene (Schlich, Wise, et al., 1989; Li et al., this volume). This material was compared with two paratype specimens supplied by the Shell Company.

\section{MORPHOLOGICAL CHARACTERS OF CASSIGERINELLOITA AMEKIENSIS}

Test Size and Chamber Characters

Early C. amekiensis has an extremely small test, with an average diameter of $70-80 \mu \mathrm{m}$ in Sample 120-749B-13X-CC, $0-3 \mathrm{~cm}$. It reached $100-110 \mu \mathrm{m}$ in breadth in Samples 120-749B-11X-2, 50-53 cm, and -11X-CC, 0-3 cm, along with a rapid increase in abundance in these higher horizons.

All chambers of $C$. amekiensis are spherical or hemispherical, with six to eight rapidly enlarging ones visible on the outside whorl (Plates 1 and 2). Some additional chambers (1-3) may develop in certain large specimens, exhibiting a range of variation within the species.

\section{Wall Texture}

The wall is microperforate, with micropores (diameter about $0.5-1 \mu \mathrm{m}$ ) penetrating the wall and small pustules on its surface. On the last one or two chambers, the pustules are generally smaller and weaker, whereas those on the earlier chambers are larger and denser (Plate 1, Figs. 2 and 6). We found no pore pits or pore mounds or surface textures other than pustules, nor did we observe a completely smooth wall.

The thickness of the wall is about $2 \mu \mathrm{m}$, but the walls thicken toward the early test, where they may reach 3-4 $\mu \mathrm{m}$ as a result of secondary calcification (Plate 1, Figs. 10 and 11).

The paratypes are similarly microperforate (pores about $1 \mu \mathrm{m}$ in diameter) and bear well-developed pustules that are almost twice as large as those on our specimens from Hole 749B. 

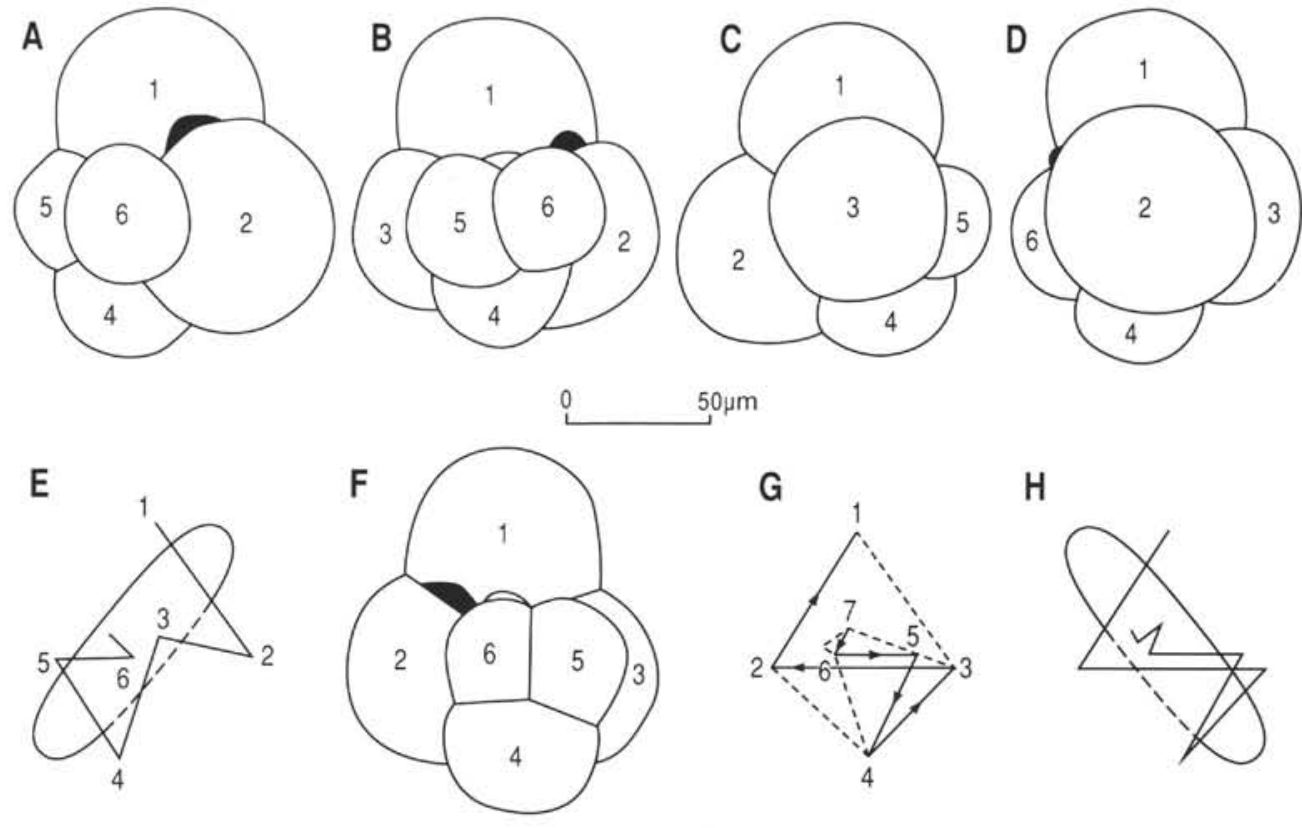

$50 \mu \mathrm{m}$

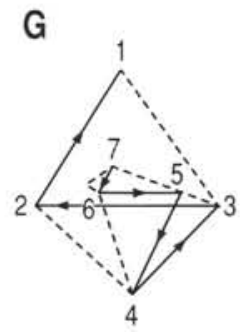

$\mathrm{H}$

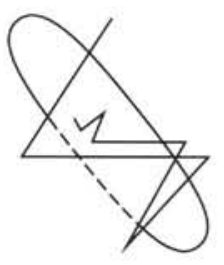

Figure 1. A-D. Line drawings based on the holotype figures of $C$. amekiensis in Stolk (1965), with successive numbering of the chambers. E. Coiling pattern in holotype (A). F. Specimen from Sample 120-749B-11X-CC, 0-3 cm (as in Plate 1, Fig. 1) with chamber centers indicated for coiling reconstruction. G. Schematic two-dimensional illustration of triserial chamber arrangement in preceding figure (F). Note that only a single alternation of direction is followed (i.e., the direction of coiling from 6 to 5 is the same as from 4 to 3 , and the direction of coiling from 5 to 4 is the same as from 3 to 2 ). $\mathbf{H}$. As in the preceding figure $(\mathrm{G})$, showing triserially pseudoplanispiral coiling.

\section{Coiling Mode}

Chambers in $C$. amekiensis are arranged triserially in a very low trochospire (= pseudoplanispire) to form a polygonal, subspherical test without a true umbilicus or distinct periphery. The successive triserial whorls are themselves coiled, so that the test (like that of Cassigerinella) has two simultaneous but distinct axes of coiling (Fig. 1). Viewed from their outer margin, or from the side opposite to the apertures, any three successive chambers always constitute a unique trigonal pattern, with the last-formed chamber situated across the suture of the previous two, in the shape of an isosceles triangle (Plate 1, Figs. 3, 5, and 6; Plate 2, Figs. 2, 3, and 5). Furthermore, in tests where the early whorls are invisible, an alternate coiling direction in the chambers suggests pseudoplanispirality. For every three consecutive chambers, only a single alternation of coiling direction occurs through ontogeny, even in specimens with the final chamber in a different position (cf. Plate 1, Figs. 1 and 10 with Plate 2, Figs. 7 and 1, respectively). This pseudoplanispirality produces a false appearance of the chambers being coiled in pairs like that in Cassigerinella, that is, the odd-numbered chambers are located on one side and the even ones on the other (Fig. 1). Biserially planispiral Cassigerinella spp., however, always possess laterally flattened tests with pseudoumbilici and a distinct periphery, to which the aperture is directed (Saito and Biscaye, 1977; Li, 1986). Three successive chambers in these flattened Cassigerinella never constitute an isosceles triangle, a basic unit in the polygonal test of $C$. amekiensis. The term "triserial pseudoplanispiral coiling" is here introduced to define the peculiar mode that characterizes $C$. amekiensis, the first record of its type among the planktonic foraminifers.

\section{Apertural Features}

A semicircular or low-arched aperture, with or without a thin lip, is clearly visible in most individuals of $C$. amekiensis and is always located across the suture between the last and penultimate chambers and the early chambers in the outer whorl. Our specimens did not have an apertural face as subspherical as in the holotype (see Fig. 1); it remains inflated as part of the spherical chamber (Plate 1, Figs. 1, 2, 4, and 9; Plate 2, Figs. 1, 4, and 9). No toothplates were observed in dissected specimens.

Some individuals may have an additional sutural aperture on the side of the chamber opposite to the primary one; in this case, several additional chambers ("bullae" of Stolk, 1965, but not of Bolli et al., 1957) may also develop on these apertures to form a test marked by chamber proliferation (Plate 1, Figs. 9, 12, and 13).

\section{AFFINITY AND PHYLOGENY}

The diagnostic morphological characters of Cassigerinelloita amekiensis, as described above, include the microperforate, pustulate wall and triserial, pseudoplanispiral coiling. Therefore, forms with these or similar characters should be considered as closely related phylogenetically. In our material, the only form with similar morphology and occurring together with $C$. amekiensis is Guembelitria triseriata (Terquem) (Plate 2, Figs. 10-12). This species, as considered here, includes all known Eocene triserial taxa, such as $G$. columbiana Howe (1939) and G. stavensis Bandy (1949), because all these morphotypes coexist in our samples and further division seems unjustified (see also McGowran and Beecroft, 1985). Guembelitria samwelli Jenkins (1978) is another similar form, but it occurs only in the middle Oligocene in southern oceans. 


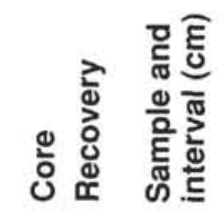

Main components (\%)

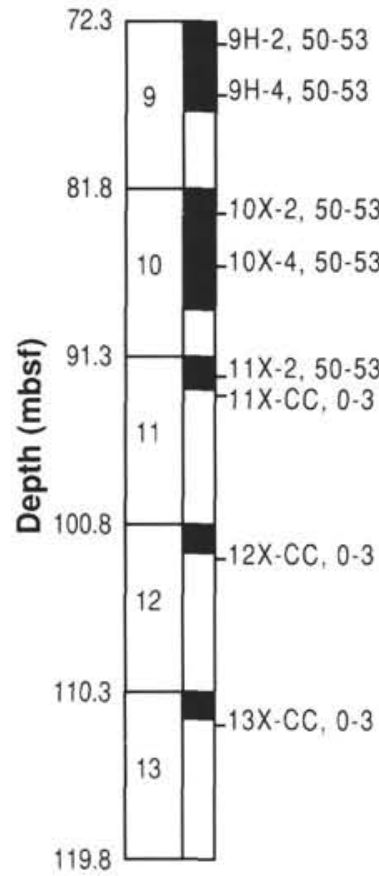

Ranges of other species

Zone Age

Figure 2. Composition of planktonic foraminifers in Cores $120-749 \mathrm{~B}-9 \mathrm{H}$ through $-13 \mathrm{X}$. Note that C. amekiensis occurs in the Acarinina bullbrooki Zone (AP8 of Stott and Kennett, in press), an interval equivalent to upper Zone PIO of Blow (1979) and Berggren and Miller (1988). See also $\mathrm{Li}$ et al. (this volume).

Guembelitria triseriata has an almost equally small but elongate test constructed of spherical chambers in a triserial coil (i.e., three in a whorl; see Plate 2, Figs. 10-12). The wall is microperforate and pustulate, with heavier pustules and maximum wall thickness in the early chambers. The aperture, bordered with a distinct lip, is semicircular or low-arched and open to the umbilicus. All these features, except the umbilicus and the test shape, have been found in $C$. amekiensis. In $G$. triseriata, the coiling mode is unidirectional and triserial, producing an elongate test; in $C$. amekiensis triserial coiling is combined with pseudoplanispiral coiling to form a subglobular test shape. Possibly, C. amekiensis originated from variants of $G$. triseriata through a change of coiling mode from triserial and highly trochospiral to triserial and pseudoplanispiral.

With this change, the aperture became slightly modified in its location, and the lip thinner to adjust to pseudoplanispirality, producing the unusual reconfiguration of the chambers in $C$. amekiensis. The combined relative abundance of $C$. amekiensis and $G$. triseriata in the fossil fauna further suggests such a relationship. In the lowermost available Sample 120-749B$13 \mathrm{X}-\mathrm{CC}, 0-3 \mathrm{~cm}, G$. triseriata and $C$. amekiensis each constituted only $5 \%$ of the fauna, and their relative proportions gradually changed to $2 \%: 10 \%$ (in Sample 120-749B-12X-CC, $0-3 \mathrm{~cm}$ ) and 1\%:40\%-35\% (in Samples 120-749B-11X-CC, $0-3 \mathrm{~cm}$, and $-11 \mathrm{X}-2,50-53 \mathrm{~cm})$. Only after the extinction of C. amekiensis in Sample 120-749B-10X-4, 50-53 cm, did G. triseriata begin to dominate the fauna (Fig. 2).

After establishing itself in the fauna, $C$. amekiensis gradually increased in test size (from $70 \mu \mathrm{m}$ in Sample 120-749B$13 \mathrm{X}-\mathrm{CC}, 0-3 \mathrm{~cm}$, to $120 \mu \mathrm{m}$ in Sample 120-749B-11X-2, 50-54 $\mathrm{cm}$ ) and achieved a rapid increase in relative abundance. Just before the species became extinct, a few supplementary apertures and bulla-like additional chambers developed on some tests (Plate 1, Figures 9, 12, and 13).

Thus, Cassigerinelloita amekiensis appears to be a direct descendant of $G$. triseriata despite the absence of intermediate forms linking the two species at Hole 749B, probably as a result of inadequate sample collection because of nonrecovery of the lowermost Core 120-749B-14X. The separation of $C$. amekiensis from $G$. triseriata must have been at a time earlier than the age of our oldest sample (120-749B-13X-CC, 0-3 $\mathrm{cm})$, but future work will resolve this.

The evidence, therefore, suggests that Blow (1979) and Loeblich and Tappan (1988) are incorrect in their consideration of the nature of $C$. amekiensis. It is not an abortive variant of ?Globigerinita, as implied by Blow, because species of Globigerinita, although having a wall similar to $C$. amekiensis, have been suggested to have evolved from Tenuitella only from the Oligocene on (see Fleisher, 1974; Li, 1987). Neither is it a catapsydracid, as suggested by Loeblich and Tappan (1988), because all catapsydracids are characterized by a distinct cancellate wall rather than the microperforate wall found in $C$. amekiensis. The so-called "microcancellate wall" of Loeblich and Tappan (1988) is possibly a mistaken identification of a pattern produced by the heavy pustules in the type illustrations of $C$. amekiensis.

As pointed out by Stolk (1965), however, C. amekiensis is morphologically similar to species of Cassigerinella, as they have similar chamber arrangement patterns, which indeed has led some authors (e.g., Banner, 1982) to suppose affinity. A previous study by $\mathrm{Li}$ (1986), however, of the Cassigerinella species $C$. chipolensis and $C$. boudecensis, confirmed that 
Table 1. Morphocharacters and ancestors of Cassigerinelloita, Cassigerinella, and Riveroinella.

\begin{tabular}{|c|c|c|c|c|}
\hline Species & $\begin{array}{c}\text { Wall } \\
\text { texture }\end{array}$ & $\begin{array}{c}\text { Coiling } \\
\text { (pseudoplanispiral) }\end{array}$ & Range & $\begin{array}{l}\text { Possible } \\
\text { ancestor }\end{array}$ \\
\hline Cassigerinelloita amekiensis & Microperforate, pustulate & Triserial & P10/AP8 & Guembelitria triseriata \\
\hline Cassigerinella boudecensis & Finely perforate, + pore mounds & Biserial & P18-?N14 & Chiloguembelina \\
\hline Cassigerinella chipolensis & Finely perforate, smooth & Biserial & ap $18-? \mathrm{~N} 14$ & Chiloguembelina \\
\hline Riveroinella martinezpicoi & Finely perforate, smooth & Biserial & $\mathrm{b}_{\text {early Miocene }}$ & ?Streptochilus \\
\hline
\end{tabular}

${ }_{\text {a Blow (1979). }}$

bermúdez and Seiglie (1967).

these are essentially biserial (but not triserial) planispires and that they evolved from a biserial Chiloguembelina. This contrasts with Cassigerinelloita, which is essentially triserial pseudoplanispiral and probably evolved from triserial Guembelitria. In addition, $C$. amekiensis can be distinguished from Cassigerinella, as well as from Riveroinella martinezpicoi (SEM illustrations in Saito and Biscaye, 1977), by its microperforate, pustulate wall rather than by a finely perforate, smooth wall or a wall with distinct pore mounds (Table 1).

\section{OCCURRENCE}

Stolk (1965) recorded C. amekiensis, together with Guembelitria "columbiana" (= G. triseriata), as ranging from the ?uppermost lower Eocene to the lower middle Eocene (the $C$. amekiensis Zone), confirmed by Petters (1983). Other species occurring in this interval include Globigerina linaperta Finlay, G. yeguaensis Weinzierl and Applin, G. boweri Bolli, Globorotalia pseudomayeri Bolli, G. renzi Bolli, Pseudohastigerina micra (Howe), and, in the lower part, "G. pseudomenardii" sensu Loeblich and Tappan (1957). Although lacking some diagnostic species (e.g., Acarinina primitiva Finlay and Globigerinatheka index Finlay), this faunal assemblage represents the early to middle Eocene in modern biostratigraphy (Blow, 1979; Toumarkine and Luterbacher, 1985; Berggren and Miller, 1988), which conforms with the original age determination by Stolk (1965).

Surprisingly, the fossil fauna from the interval with $C$. amekiensis in Hole 749B is similar, if not identical in age, to the one recorded by Stolk in Nigeria. Acarinina primitiva and Guembelitria triseriata occurred throughout the range of $C$. amekiensis, and $G$. index made its first appearance some $10 \mathrm{~m}$ above the extinction of $C$. amekiensis (Fig. 2). This approximates Zones P10 to lower P11 because, according to McGowran (1977) and McGowran and Beecroft (1985), the last appearance datum (LAD) of Planorotalites australiformis (Jenkins) and the first appearance datum (FAD) of $G$. index can be correlated to within Zone P11. Just below this, in the lower part of Zones P11 and P10, Guembelitria occurred in southern Australia and in Sites 214 and 264 in the eastern Indian Ocean. Because $C$. amekiensis disappeared much earlier than the extinction level of Guembelitria at Hole 749B, we now propose a range for $C$. amekiensis to be within Zone P10, or Zone AP8 (of Stott and Kennett, 1990) in the early middle Eocene (Fig. 2; see also $\mathrm{Li}$ et al., this volume).

Stott and Kennett (1990) recorded some similar forms in Hole 689B (Leg 113, Maud Rise, Antarctica) in their Zone AP8, equivalent to tropical Zone P10 (upper part), in Chron 21 , about $50 \mathrm{Ma}$ in the chronostratigraphy of Berggren et al. (1985). Their specimens, figured as Globigerina? sp. B on Plate 5, Figures 11-14, appear to belong to C. amekiensis.

\section{PALEOCEANOGRAPHIC SIGNIFICANCE}

Modern representatives of triserial Guembelitria, the microperforate Gallitellia vivans (Cushman), inhabit the water column between Globigerinoides trilobus (surface dweller) and Globorotalia menardii (deep dweller) in open-marine environments. They are especially common, however, in unstable conditions such as upwelling waters (Kroon and Nederbragt, 1988). Except in its smooth wall and lipless, asymmetric aperture, Gallitellia vivans closely resembles the fossil Guembelitria triseriata. The latter has been reported as occurring from the middle Eocene to the lower Oligocene (Beckmann, 1957, as G. columbiana), but it became common to abundant only in sediments of the early middle Eocene (Zones P10-P11), a period of cooling according to McGowran and Beecroft (1985), for example. The onset of the middle Eocene saw a drop in global temperature after a long warm period in the early Eocene, as recorded by isotopic studies (e.g., Shackleton and Kennett, 1975, Tasman Sea; Shackleton, 1986, summary of Paleogene; Boersma et al., 1987, Atlantic Ocean). In response to this cooling, however, planktonic foraminifers showed a gradual transformation rather than a rapid faunal turnover from morozovellid to subbotinid assemblages (see Haq et al., 1977, and Premoli Silva and Boersma, 1988, for the Atlantic Ocean).

McGowran and Beecroft (1985) first proposed that G. triseriata might be a cool-water indicator based on the disappearance of large benthic foraminifers in the early middle Eocene. Whether G. triseriata, as well as its probable offshoot Cassigerinelloita amekiensis, was an upwelling inhabitant, as is its present-day counterpart Gallitellia vivans, or a cool-water indicator, or both, is not yet fully understood. However, the invasion of $G$. triseriata alone is insufficient to indicate such a cooling event in the early middle Eocene. It is unlikely that Nigeria (equatorial) and southern Australia and the Kerguelen Plateau (subantarctic) were all under similar cool-water conditions, as indicated by a similar fauna, including G. triseriata, found in these areas during the early middle Eocene.

The evidence listed below supports our view that $G$. triseriata is an indicator of unstable (upwelling) waters:

1. Upwelling waters are presently usually dominated by small forms (Duplessy et al., 1981), such as Gallitellia vivans (Kroon and Nederbragt, 1988).

2. Guembelitria triseriata first occurred at the beginning of the middle Eocene, a period of invigorated upwelling accompanied by a strong, widely developed oxygen minimum, as indicated by high abundances of biserial Chiloguembelina in Atlantic regions (Boersma and Premoli Silva, 1988).

3. A synchronous hiatus has been widely recorded near the early Eocene-middle Eocene boundary in the Southern Oceans (McGowran, 1977; Stott and Kennett, 1990), indicating unstable marine environments (McGowran, 1978).

4. A change of sedimentation rates from $>70 \mathrm{~m} / \mathrm{m}$.y. (early Eocene) to about $8 \mathrm{~m} / \mathrm{m} . \mathrm{y}$. (middle to late Eocene) was recorded at Hole 749B (Schlich, Wise, et al., 1989), and at that level both Guembelitria triseriata and Cassigerinelloita amekiensis occurred (this study). This indicates that environmental changes such as increasing productivity might have caused the evolution of these taxa. 
5. The scattered geographic record of $C$. amekiensis suggests that this species is an indicator of unusual conditions.

6. The middle Eocene in the Gulf of Guinea, including the type locality of $C$. amekiensis, is characterized by coastal upwelling and phosphate sedimentation (Petters, 1981, 1983).

Originating from $G$. triseriata, $C$. amekiensis might have inhabited similar unstable environments such as upwelling waters but with a rather limited spatial dispersal.

\section{CONCLUSIONS}

Cassigerinelloita amekiensis possesses a microperforate, pustulate wall and a peculiar, triserial, pseudoplanispiral coiling mode. It resembles a co-occurring triserial species, Guembelitria triseriata, in many morphological aspects. $C$. amekiensis may have evolved from $G$. triseriata by a change of coiling mode from triserial and rectilinear coiling to triserial and pseudoplanispiral coiling, in unstable or upwelling waters at about $50 \mathrm{Ma}$, equivalent to Zone P10, or Zone AP8, in the early middle Eocene.

Accordingly, the genus Cassigerinelloita should be classified in the family Guembelitriidae (given below), rather than in the families Catapsydracidae or Cassigerinellidae, as proposed elsewhere.

The phylogenetic importance of wall texture, as discovered earlier by Lipps (1966) and Steineck and Fleisher (1978), is confirmed again by a reconstruction of the $G$. triseriata-C. amekiensis lineage in this study.

\section{SYSTEMATIC DESCRIPTION}

\section{Family GUEMBELITRIIDAE Montanaro Gallitelli, 1957 Genus CASSIGERINELLOITA Stolk, 1965, emended (type species: C. amekiensis Stolk, 1965)}

Emended Description. Test small, about $70-120 \mu \mathrm{m}$ in diameter, globular; chambers spherical, six to eight visible in the complete test, arranged triserially and pseudoplanispirally, without a true umbilicus; wall microperforate and pustulate; aperture interiomarginal, low arched, with or without a thin lip, situated on the suture and sited between the last two chambers and the early chambers of the outer whorl; rarely, up to three nontriserial additional chambers are formed terminally with their own sutural apertures.

Range. Zone P10/AP8 (lower middle Eocene).

Distribution. Nigeria, southern Indian Ocean, Weddell Sea.

\section{ACKNOWLEDGMENTS}

We are indebted to W. A. Berggren for inviting us to study material from Leg 120. We acknowledge the ODP Curator and other staff for assistance in obtaining samples. K. James, J. Parker, and P. Barbeito kindly arranged supplies of type material from Nigeria. F. T. Banner read an early draft of this report, and L. D. Stott and A. J. Nederbragt reviewed the manuscript. The camera-ready art for text figures was prepared by A. R. Brown. We particularly thank E. Thomas and E. Barbu for editorial work. This study was supported by a Hui Fellowship at Imperial College, London.

\section{REFERENCES}

Bandy, O. L., 1949. Eocene and Oligocene foraminifera from Little Stave Creek, Clarke County, Alabama. Bull. Am. Paleontol., 32:35-240.

Banner, F. T., 1982. A classification and introduction to the Globigerinacea. In Banner, F. T., and Lord, A. R. (Eds.), Aspects of Micropalaeontology: London (Allen \& Unwin), 142-239.

Beckmann, J. P., 1957. Chiloguembelina Loeblich and Tappan and related Foraminifera from the lower Tertiary of Trinidad, B. W. I. Bull. U.S. Nat. Mus., 215:83-95.

Berggren, W. A., and Miller, K. G., 1988. Paleogene tropical planktonic foraminiferal biostratigraphy and magnetobiochronology. Micropaleontology, 34:362-380.
Bermúdez, P. J., and Seiglie, B. S., 1967. A new genus and species of foraminifer from the early Miocene of Puerto Rico. Tulane Stud. Geol. 5:177-179.

Blow, W. H., 1979. The Cainozoic Globigerinida: Leiden (E. J. Brill).

Boersma, A., and Premoli Silva, I., 1987. Boundary conditions of Atlantic Eocene oxygen minimum zones. Riv. Ital. Paleontol. Stratigr., 93:479-506.

Boersma, A., Premoli Silva, I., and Shackleton, N. J., 1987. Atlantic Eocene planktonic foraminiferal paleohydrographic indicators and stable isotope paleoceanography. Paleoceanography, 2:287-331.

Bolli, H. M., Loeblich, A. R., Jr., and Tappan, H., 1957. Planktonic foraminiferal Families Hantkeninidae, Orbulinidae, Globorotaliidae, and Globotruncanidae. Bull. U.S. Nat. Mus., 215:3-50.

Duplessy, J. C., Bé, A.W.H., and Blanc, P. L., 1981. Oxygen and carbon isotopic composition and the biogeographic distribution of planktonic foraminifera in the Indian Ocean. Palaeogeogr., Palaeoclimatol., Palaeoecol., 33:9-47.

Fleisher, R. L., 1974. Cenozoic planktonic foraminifera and biostratigraphy, Arabian Sea, Deep Sea Drilling Project, Leg 23A. In Whitmarsh, R. B., Weser, O. E., Ross, D. A., et al., Init. Repts. DSDP, 23: Washington (U.S. Govt. Printing Office), 1001-1072.

Haq, B. U., Premoli Silva, I., and Lohmann, G. P., 1977. Calcareous plankton paleobiogeographic evidence for major climatic fluctuations in the early Cenozoic Atlantic Ocean. J. Geophys. Res., 82:3861-3876.

Howe, H. V., 1939. Louisiana Cook Mountain Eocene foraminifera. Bull. Louisiana Geol. Surv., 14:1-122.

Jenkins, D. G., 1978. Guembelitria samwelli Jenkins, a new species from the Oligocene of the Southern Hemisphere. J. Foraminiferal Res., 8:132-137.

Kroon, D., and Nederbragt, A. J., 1988. Morphology and (paleo)ecology of living and fossil triserial planktonic foraminifera. In Brummer, G.-J.A. and Kroon, D. (Eds.), Planktonic Foraminifers as Tracers of Ocean-Climate History: Amsterdam (Free Univ. Press), 181-201.

Li, Q., 1986. Ultrastructure, morphology, affinities and reclassification of Cassigerinella Pokorny (Foraminiferida: Globigerinina). J. Micropalaeontol., 5:49-64.

1987. Origin, phylogenetic development and systematic taxonomy of the Tenuitella plexus (Globigerinitidae, Globigerinina). J. Foraminiferal. Res., 17:298-320.

Lipps, J. H., 1966. Wall structure, systematics and phylogeny studies of Cenozoic planktonic foraminifera. J. Paleontol., 40:1257-1274.

Loeblich, A. R., Jr., and Tappan, H., 1957. Planktonic foraminifera of Paleocene and early Eocene age from the Gulf and Atlantic Coastal Plains. Bull. U.S. Nat. Mus., 215:173-198.

1988. Foraminiferal Genera and their Classification: New York (Van Nostrand Reinhold).

McGowran, B., 1977. Maastrichtian to Eocene foraminiferal assemblages in the northern and eastern Indian Ocean region: correlations and historical patterns. In Heirtzler, J. R., Bolli, H. M., Davies, T. A., Saunders, J. B., and Sclater, J. C. (Eds.), Indian Ocean Geology and Biostratigraphy: Washington (Am. Geophys. Union), 417-458.

1978. Stratigraphic record of early Tertiary oceanic and continental events in the Indian Ocean region. Mar. Geol., 26:139.

McGowran, B., and Beecroft, A., 1985. Guembelitria in the early Tertiary of southern Australia and its palaeoceanographic significance. In Lindsay, J. M. (Ed.), Stratigraphy, Palaeontology, Malacology: Papers in Honour of Dr. Nell Ludbrook. S. Aust. Dept. Mines Energy, Spec. Publ., 5:247-261.

Montanaro Gallitelli, E., 1957. A revision of the foraminiferal family Heterohelicidae. Bull. U.S. Nat. Mus., 215:133-154.

Nocchi, M., Amici, E., and Premoli Silva, I., 1991. Planktonic foraminiferal biostratigraphy and paleoenvironmental interpretation of Paleogene fauna from Subantarctic Transect, Leg 114. In Ciesielski, P. F., Kristoffersen, Y., et al., Proc. ODP, Sci. Results, 114: College Station, TX (Ocean Drilling Program).

Petters, S. M., 1981. Eocene foraminifera from clastic and phosphatic beds of the Gulf of Guinea. In Neal, J. W., and Brasier, M. D. (Eds.), Microfossils from Recent and Fossil Shelf Seas: Chichester (Ellis Horwood), 214-230. 
1983. Gulf of Guinea planktonic foraminiferal biochronology and geological history of the South Atlantic. J. Foraminiferal Res., 13:32-59.

Premoli Silva, I., and Boersma, A., 1988. Atlantic Eocene planktonic foraminiferal historical biogeography and paleohydrographic indices. Palaeogeogr., Paleoclimatol., Palaeoecol., 67:315-356.

Saito, T., and Biscaye, P. E., 1977. Emendation of Riveroinella martinezpicoi Bermudez and Seiglie, 1967, and synonymy of Riveroinella with Cassigerinella Pokorny 1955. Micropaleontology, 23:319-329.

Schlich, R., Wise, S. W., Jr., et al., 1989. Proc. ODP, Init. Repts., 120: College Station, TX (Ocean Drilling Program).

Shackleton, N. J., 1986. Paleogene stable isotope events. Palaeogeogr., Palaeoclimatol., Palaeoecol., 57:91-102.

Shackleton, N. J., and Kennett, J. P., 1975. Paleotemperature history of the Cenozoic and the initiation of Antarctic glaciation: oxygen and carbon isotope analyses in DSDP Sites 277,279 and 281. In Kennett, J. P., Houtz, R. E., et al., Init. Repts. DSDP, 29: Washington (U.S. Govt. Printing Office), 743-755.

Steineck, P. L., and Fleisher, R. L., 1978. Towards the classical evolutionary reclassification of Cenozoic Globigerinacea (Foraminiferida). J. Paleontol., 52:618-635.

Stolk, J., 1965. Contribution à l'ètude des correlations microfaunique du Tertiaire inférieur de la Nigèrie méridionale. Mem. BRGM, 32:247-267.
Stott, L. D., and Kennett, J. P., 1990. Antarctic Paleogene planktonic foraminifer biostratigraphy: ODP Leg 113, Sites 689 and 690. In Barker, P. F., Kennett, J. P., et al., Proc. ODP, Sci. Results, 113: Washington (U.S. Govt. Printing Office), 549-569.

Toumarkine, M., and Luterbacher, H., 1985. Paleocene and Eocene planktic foraminifera. In Bolli, H. M., Saunders, J. B., and Perch-Nielsen, K. (Eds.), Plankton Stratigraphy: Cambridge (Cambridge Univ. Press), 87-154.

Date of initial receipt: 15 October 1989

Date of acceptance: 23 August 1990

Ms 120B-189

\section{POSTSCRIPT}

Since this report was written, we have been informed that Cassigerinelloita amekiensis also occurs in a level equivalent to Zones P9 (upper part) and P10 at Holes 698A, 699A, 700B, $702 \mathrm{~B}, 703 \mathrm{~A}$, and 704B in the subantarctic South Atlantic Ocean (Nocchi et al., 1991). 

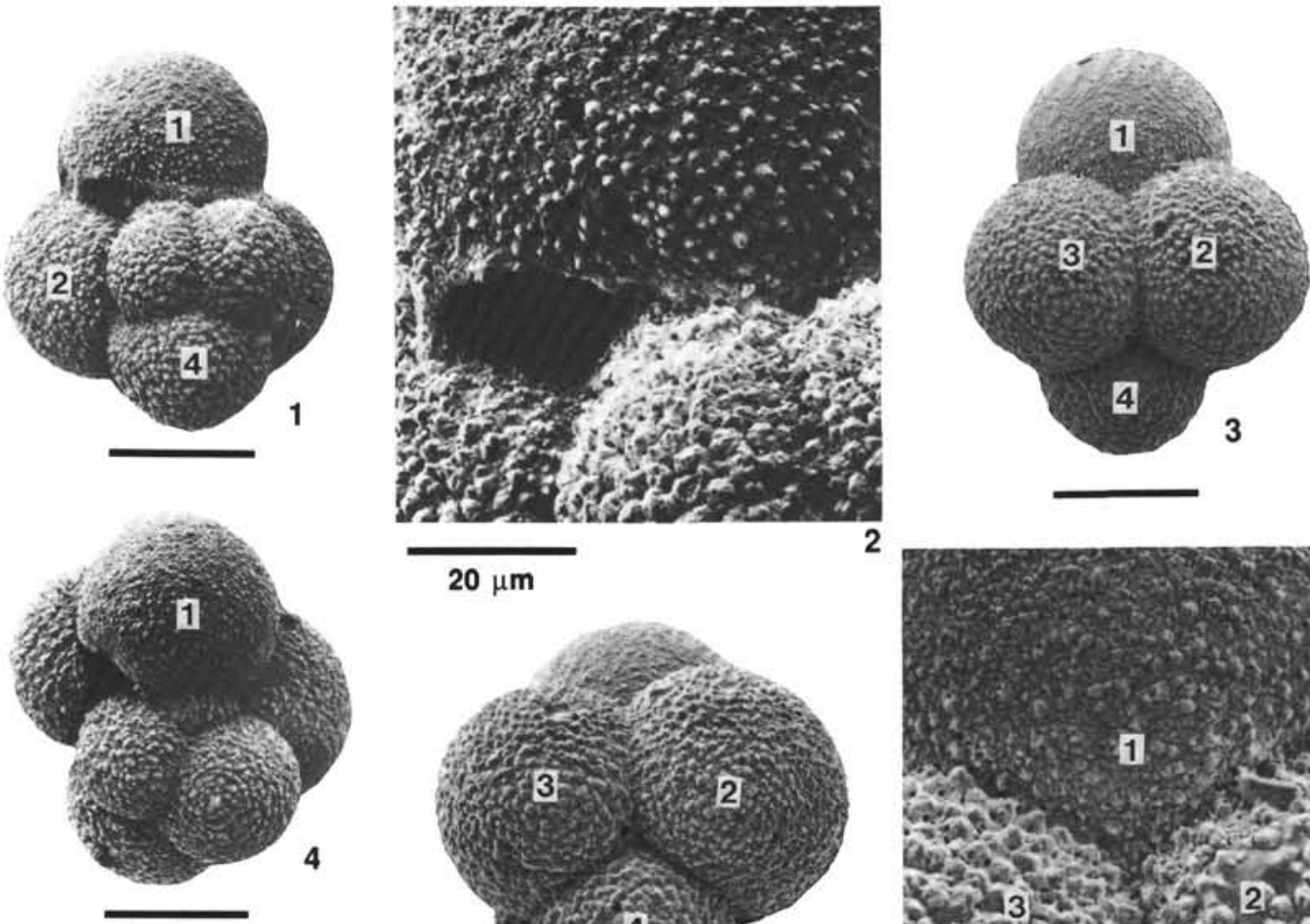

$20 \mu \mathrm{m}$

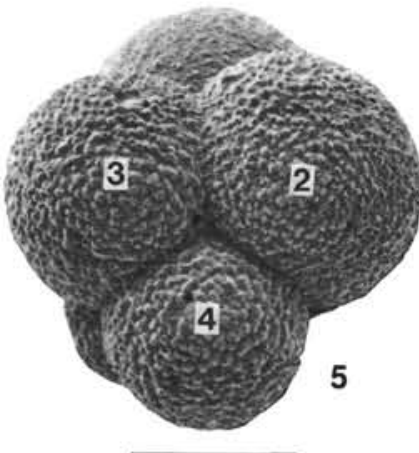

,
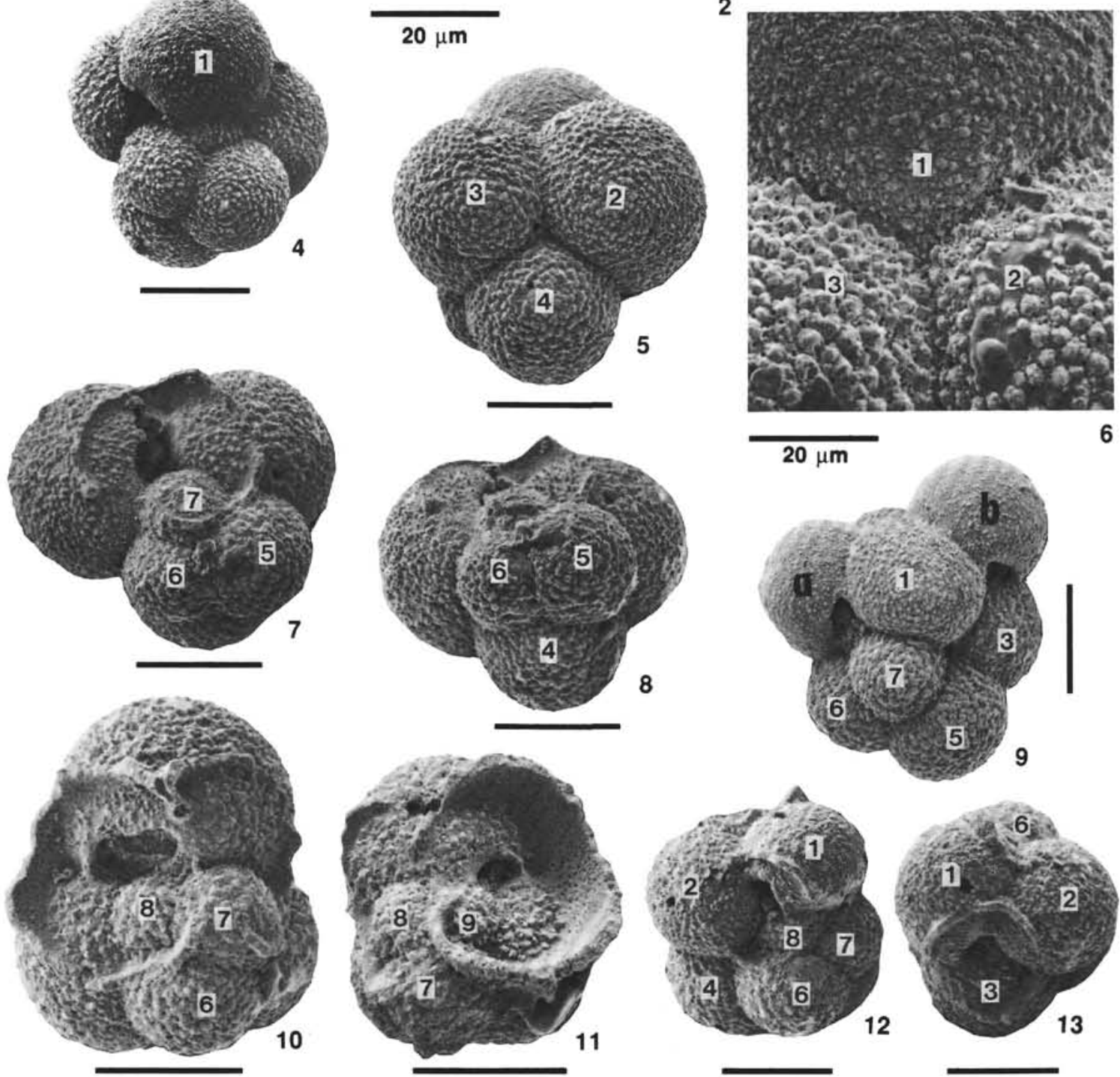

Plate 1. Scale bar for all specimens $=50 \mu \mathrm{m}$, unless otherwise indicated. 1-8, 10, 11. A single specimen of Cassigerinelloita amekiensis from Sample 120-749B-11X-CC, 0-3 cm; (1) apertural view; (2) apertural closeup showing a weakly developed lip and microperforate, pustulate wall; (3) side view of the last four chambers that shows the trigonal pattern of last three successive chambers; (4) tilted view of Plate 1, Figure 1; (5) tilted view of Plate 1, Figure 3, showing chambers 2, 3, and 4 , which constitute another trigonal pattern; (6) enlargement of Plate 1, Figure 3; (7) final chamber removed to show the early aperture and trigonal pattern formed by chambers 5,6 , and $7 ;(8)$ tilted view of Plate 1, Figure 7; (10) final two chambers removed; (11) final three chambers removed to show the thickened wall and heavy pustules in early chambers. 9, 12, 13. A single specimen of $C$. amekiensis with supplementary apertures and additional chambers from Sample 120-749B-11X-2, 50-53 cm; (9), whole specimen with two additional chambers (a and b), which are not coiled triserially or planispirally; (12) additional chambers removed, to show the primary aperture on which additional chamber a formed; (13) tilted view of Plate 1, Figure 12, showing the additional aperture on which additional chamber $\mathbf{b}$ formed. 

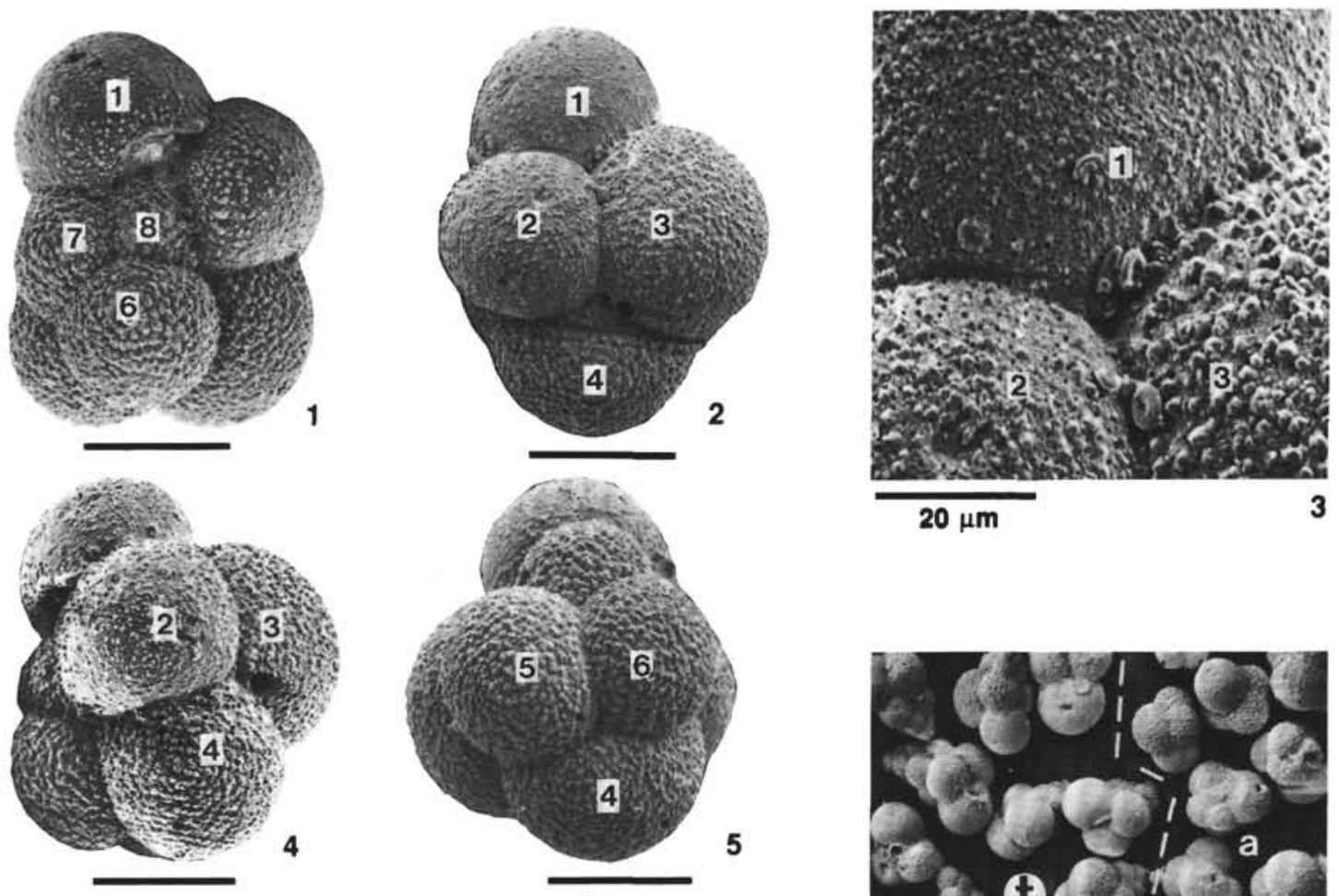

$20 \mu \mathrm{m}$
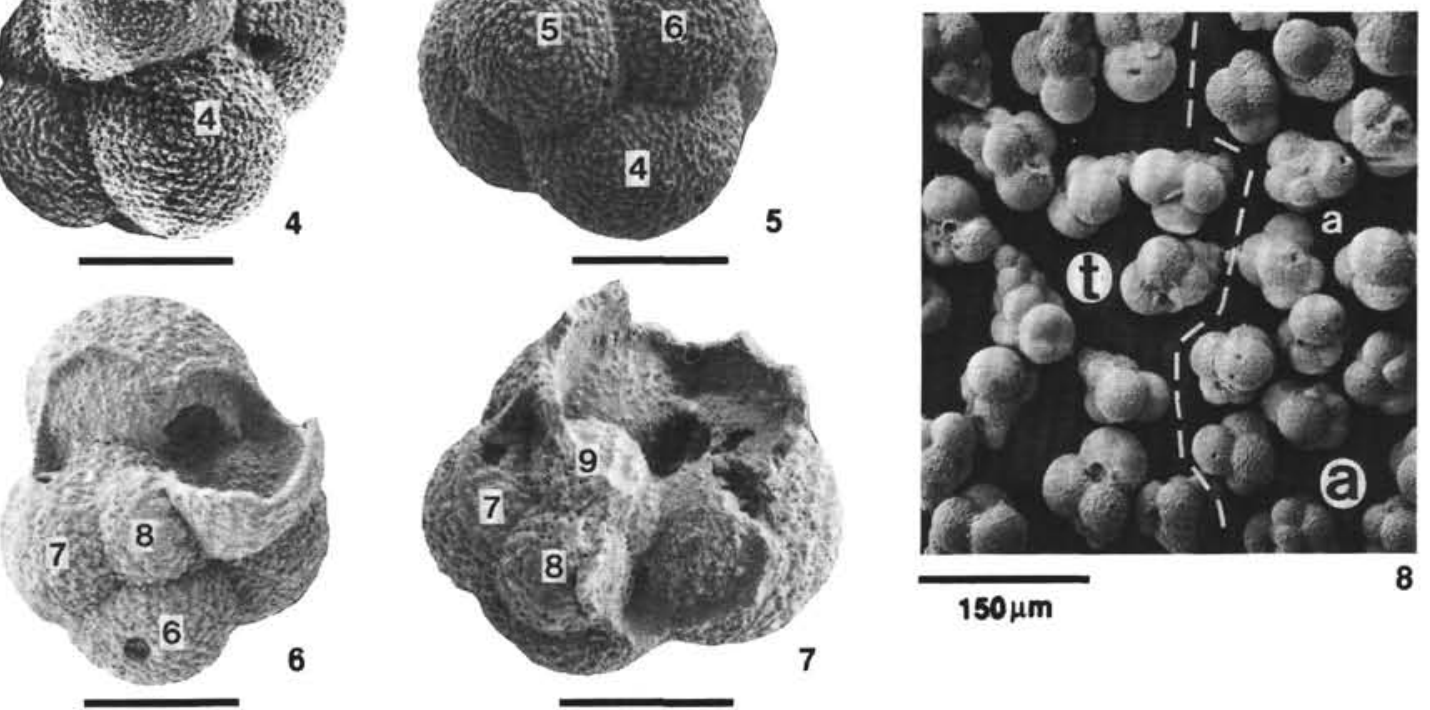

$150 \mu \mathrm{m}$
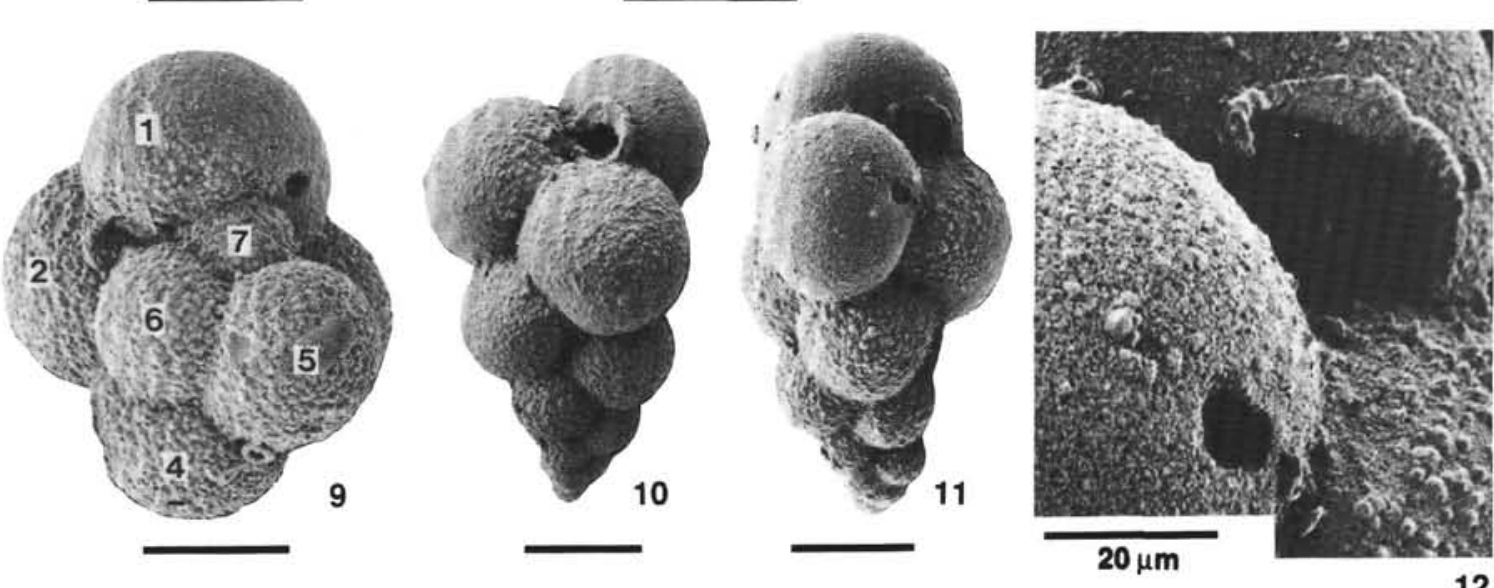

12

Plate 2. Scale bar for all specimens $=50 \mu \mathrm{m}$, unless otherwise indicated. 1-7. A single specimen of $C$. amekiensis from Sample 120-749B-11X-2, 50-53 cm; (1) aperture view; (2) outer marginal view showing trigonal patterns of chambers 1,2, and 3 and 2,3, and 4, respectively; (3) enlarged from Plate 2, Figure 2; (4 and 5) tilted views of Plate 2, Figure 1; (6) last two chambers removed to show early aperture and chambers; and (7) last three chambers removed. 8. Population of $G$. triseriata $(\mathrm{t})$ and $C$. amekiensis (a) from Sample 120-749B-13X-CC, $0-3 \mathrm{~cm}$. Note that their tests are almost equally small. 9. A single specimen of $C$. amekiensis with a small aperture from Sample 120-749B-11X-2, 50-53 cm. 10-12. Two specimens of $G$. triseriata from Sample 120-749B-10X-4, 50-53 cm; (10) specimen with spherical chambers; (11) specimen with oval to spherical chambers; (12) enlargement of Plate 2, Figure 11, showing the microperforate, pustulate wall and well-developed apertural lip. 